\title{
Teología de la eucaristía desde las plegarias eucarísticas
}

\author{
Francisco Taborda \\ FACULDADE JESUÍTA DE FILOSOFIA E TEOLOGIA \\ BELO HORIZONTE
}

Para abordar sobre este tema hay que explicitar primero el principio lex orandi - lex credendi (1.). Si aceptamos este axioma como válido, el camino más propio para desarrollar la teología de la eucaristía será el análisis de las plegarias eucarísticas (en adelante: PEs) de Oriente y Occidente. Entretanto, por cuestión de espacio, nos detendremos en el esquema general de las plegarias de la liturgia romana, recurriendo a veces a otras PEs. Pero previo a la consideración de las plegarias romanas, esbozaremos rápidamente algo sobre la estructura literaria de ese tipo de oración de la Iglesia. El género de esas plegarias debe ser identificado como una oración de alianza tal como encontramos en la tradición vétero-testamentaria, continuada en el judaísmo (2.). Solamente después de esos preámbulos, podremos hacer un análisis de las PEs romanas y, desde ahí, desarrollar la teología de la eucaristía contenida en su mismo texto central: la plegaria eucarística (en adelante: PE) o -según la terminología de las Iglesias Orientales- la anáfora (3.).

\section{EL PRINCIPIO LEX ORANDI - LEX CREDENDI ${ }^{1}$}

Para comprender el axioma lex orandi - lex credendi hay que partir de su origen y formulación primera (1.1) y preguntar luego sobre sus condiciones de validad (1.2), ya que no se trata de un principio absoluto ni su formulación es evidente y exenta de ambigüedades.

1 Cf. F. TAвоRda, O memorial da Páscoa do Senhor. Ensaios litúrgico-teológicos sobre a eucaristia (Theologica; Loyola, São Paulo 2009) 21-37. Ahí una bibliografía más amplia. 
1.1 La formulación de Próspero de Aquitania y su contexto original ${ }^{2}$

La primera formulación del principio la encontramos en el opúsculo De gratia Dei et libero voluntatis arbitrio, de Próspero de Aquitania († después de 455$)^{3}$. Su intención es combatir el semipelagianismo, recurriendo primero a la autoridad de los papas y, luego, en el punto que nos interesa, a un raciocinio teológico desde la plegaria universal de la Iglesia.

Para probar su tesis de que tanto «los inicios de la buena voluntad como los progresos debidos a esfuerzos dignos de alabanza y también la perseverancia en ellos hasta el fin» provienen de la gracia de Dios, Próspero recuerda "los sacramentos de las súplicas sacerdotales» en que se pide a Dios por infieles, idólatras, judíos, heréticos, cismáticos, apóstatas, catecúmenos. En suma, por personas alejadas de la verdadera fe que o bien ya hayan tenido fe (infieles, heréticos), o bien que aún no la tengan (idólatras, judíos), o incluso que, tocados por la gracia, estén a camino de abrazarla (catecúmenos). Ahora bien, esas personas muchas veces se convierten y damos gracias a Dios por su conversión, atribuyéndola a la oración de la Iglesia. Eso significa que es la gracia así implorada la que ha alcanzado la misericordia de Dios a favor de esas personas.

Así, la oración por los alejados, que la Iglesia ha aprendido de los apóstoles y practica por toda parte, en todas las Iglesias, es la prueba de

2 Véase el amplio estudio histórico de K. Federer, Liturgie und Glaube. Eine theologiegeschichtliche Untersuchung. (Paulusverlag, Freiburg in der Schweiz 1950). P. DE Clerck, «Lex orandi, lex credendi. Sens originel et avatars historiques d'un adage équivoque», en Questions Liturgiques, 59 (1978) 193-212, 194-206. G. Wainwright, Doxology. The Praise of God in Worship, Doctrine and Life. A Systematic Theology. (Oxford University Press, New York 1980) 218-283, especialmente 224235. C. Giraudo, Num só corpo. Tratado mistagógico sobre a eucaristia. Traducido por F. TAвorda (Theologica; Loyola, São Paulo 2003) 22-27. (Original italiano: In unum corpus. Trattato mistagogico sull'eucaristia (San Paolo, Cinisello Balsamo [Milano] 2011). P. DE ClerCK, «La prière universelle, expression de la foi», en A. Pistoia - A. M. Triacca (ed.) La liturgie, expression de la foi. Conférences de SaintSerge. XXVE Semaine d'Études Liturgiques. Paris, 27 - 30 Juin 1978 (C. L. V. - Ed. Liturgiche, Roma 1979) 129-146.

3 Cf. Próspero de Aquitania, De gratia Dei et libero voluntatis arbitrio, 8 (PL 51, 209-210). Este texto se encuentra en $D H$ 246, porque fue por mucho tiempo atribuido al papa Inocencio I, además de constituir, en parte, una colectánea de citaciones de textos de obispos de Roma. La obra es también llamada Capitula de gratia. 
la prioridad de la gracia. En este contexto Próspero creó este principio tan denso como profundo: ut legem credendi lex statuat supplicandi (para que la ley de la súplica establezca la ley de la fe). Si la formulación sintética y vigorosa del principio es de Próspero, su contenido es anterior. Lo encontramos en Agustín que formula el principio de distintas maneras. Así, por ejemplo, refiriéndose al pedido del Padre-Nuestro «no nos dejes caer en la tentación», escribe: «La misma oración es un testimonio clarísimo de la gracia» ${ }^{4}$.

Agustín, por su parte, no es el primero en asumir la oración de la Iglesia como criterio de fe. Antes que él, otro africano, Cipriano de Cartago $(† 258)$ lo ha hecho en su comentario al Padre Nuestro, cuando afirma que esta oración es norma de la vida cristiana. En este contexto usa incluso la expresión que Próspero adoptará después: la lex orandi ${ }^{5}$. Pero, al reflexionar sobre la lex orandi, Cipriano la considera más como norma para la vida cristiana o para la ortopraxis, que para la verdad de fe o la ortodoxia.

\subsection{Condiciones de validad}

Ahora hay que preguntarse por las condiciones supuestas por el axioma para que sea válido como norma de fe confesada (Agustín) y como norma de fe practicada (Cipriano).

En el mismo texto del Indiculus de gratia, Próspero supone que la práctica de «las súplicas sacerdotales» proviene de los apóstoles, es decir,

4 Agustín de Hipona, Ep. 177, 4 (PL 33, 766): Ipsa igitur oratio clarissima est gratiae testificatio. ID.: Ep. 217, 2 e 6 (PL 33, 978-981). Aquí entraría en cuestión toda la Ep. 217 y especialmente el resumen que Agustín hace al final Ep. 217, 30 (PL 33, 989) y el De dono perseverantiae 23, 63-65 ( $P L 45,1031-1033)$ más en particular el número 63, col. 1031-1032.

5 Cf. Cipriano de Cartago, De oratione Dominica 8 (PL 4, 524): sic orare unum pro omnibus voluit, quomodo in uno omnes ipse portavit (El Señor «quiso que uno orara por todos, como él mismo cargó a todos en uno»). Ib., 20 (PL 4, 533): Ad quod ut possit unusquisque nostrum parare se, sic discat orare et de orationis lege qualis esse debeat noscere (Para que cada uno de nosotros pueda prepararse, aprenda a orar y a conocer cual debe ser la ley de la oración). ID., De catholicae ecclesiae unitate, 13 (SChr 500, 212-213): Ideo et cum orandi legem daret, addidit dicens: «Et cum steteritis ad orationem, remittite» (Por eso, cuando dio la ley del orar, añadió diciendo: «Y cuando estuviereis de pie para la oración, perdonad»). 
de la Sagrada Escritura y que está en uso por toda parte, en todas las Iglesias. Ahora bien, cuál es la importancia de este supuesto.

En De vocatione omnium gentium, obra escrita en Roma por el año $450^{6}$, Próspero explicita la fundamentación de «las súplicas sacerdotales» en un texto de la Escritura. El contexto es también la polémica con los semipelagianos. Estos acusan a los seguidores de Agustín, diciendo que niegan la voluntad salvífica universal de Dios, claramente atestiguada en 1Tm 2, 1-6. Próspero los refuta, apuntando al contexto de esa afirmación que es la recomendación para que se hagan oraciones en favor de todos los seres humanos. Próspero ve en esta perícopa una determinación de Dios, una ley transmitida por el apóstol. Como en el Indiculus, Próspero habla de la lex supplicandi, aquí en De vocatione identifica la determinación del autor como un ordo supplicationis, aunque el texto no imponga una obligación y sea una mera recomendación.

Próspero añade todavía que el ordo supplicationis es obedecido por toda la Iglesia, en todo lugar. Eso es fundamental para la polémica. Su contemporáneo semipelagiano Vicente de Lérins († por 450) establece como criterio de identificación de lo que «es verdadera y propiamente católico» el principio: «lo que en todo lugar, siempre y por todos ha sido creído" (quod ubique, quod semper, quod ab omnibus creditum est) ${ }^{7}$. Si es así, los semipelagianos tendrán que aceptar el argumento de Próspero, pues lo que escribe Vicente de Lérins puede perfectamente ser aplicado a la oración de la Iglesia: «lo que en todo lugar, siempre y por todos ha sido orado» debe ser aceptado como «verdadera y propiamente católico».

Así, en consecuencia de esos principios, se puede y debe creer en el contenido supuesto por la práctica de la Iglesia. El ordo supplicationis, dado en la primera carta a Timoteo, ha sido siempre obedecido por la Iglesia bajo la orientación del Espíritu Santo y de este modo «determina la regla de la fe».

Tendríamos, pues, tres criterios para calificar la lex orandi: 1) Lo que más pesa para determinar lo que pertenece a la lex orandi es el testimonio de la Escritura, su fundamentación bíblica. 2) Esta, a su vez, es asegurada por el uso de la Iglesia, el sensus Ecclesiae que se expresa en la práctica litúrgica. Este uso tiene tanto más peso si es de origen apostólico y

6 Cf. Próspero de Aquitania, De vocatione omnium gentium I, 12 (PL 51, 664-665).

7 Vicente de Lérins, Commonitorium I, 2 (PL 50, 640). 
seguido desde siempre por todas las Iglesias en todo el mundo (semper et ubique). 3) Solamente entonces entra en cuestión el contenido de la plegaria de la Iglesia. Es decir, con palabras de P. De Clerck: «La liturgia es lugar teológico en la medida en que se funda sobre la Escritura y en que da, de la Tradición viva, su eco particular, que es poético, simbólico y existencial, más bien que racional» ${ }^{8}$.

Establecido el principio lex orandi - lex credendi, analizaremos a continuación la estructura propia de las PEs, ya que es la anáfora el corazón de la celebración eucarística. Según la hipótesis plausible de Cesare Giraudo, la plegaria hecha sobre el pan y el vino en memorial de la Pascua del Señor es la forma primera de celebrar la eucaristía ${ }^{9}$. Esta plegaria, usada desde siempre en la Iglesia, responde al triple criterio de Próspero. Pero, para entenderla, es necesario explicitar su estructura propia, íntimamente ligada a la teología de la alianza de Dios con la humanidad.

\section{LA ESTRUCTURA LITERARIO-TEOLÓGICA DE LOS TEXTOS DE ALIANZA Y DE} LA PLEGARIA DE ALIANZA (TODÁ) ${ }^{10}$

Las anáforas pueden ser clasificadas dentro del género literario litúrgico de "plegaria de alianza», usado también en otras plegarias fundamentales en la celebración de los sacramentos, tales como la bendición del agua en el bautismo, la bendición nupcial en el matrimonio, las bendiciones de los óleos del crisma, de los enfermos y de los catecúmenos y las plegarias de ordenación ${ }^{11}$. En su forma literaria, esas plegarias derivan de la todá o confesión usada en el Antiguo Testamento y en el judaísmo. Confesión, porque en ellas se reconocen los propios pecados y, al mismo tiempo la acción de Dios, su fidelidad y su voluntad salvífica. En el caso de las plegarias cristianas de alianza, la confesión, en general, tiene por objeto

8 P. De Clerck, «Lex orandi, lex credendi. Sens originel et avatars historiques d'un adage équivoque», 206.

9 C. Giraudo, Num só corpo, 233-253.

10 Cf. C. Giraudo, Num só corpo, 187-231. F. Taborda, O memorial da Páscoa do Senhor, 87-94.

11 Cf. M. B. Merz, "Gebetsformen der Liturgie», en H. B. Meyer (org.) Gottesdienst der Kirche. Handbuch der Liturgiewissenschaft 3: Gestalt des Gottesdienstes. Sprachliche und nichtsprachliche Ausdrucksformen (Pustet, Regensburg 1987) 116-120. La designación de ese tipo de plegarias, en alemán, es Hochgebet y significa tanto como oración alta, elevada $(H o c h=$ alto, elevado; Gebet $=$ oración $)$. Podríamos llamar de plegaria solemne. 
la acción salvífica de Dios que culmina en su autocomunicación por Cristo en el Espíritu Santo. Sea como sea, la estructura de esas plegarias solemnes corresponde a la dinámica teológica de la relación de alianza entre Dios y la humanidad. De ahí su nombre.

La estructura de alianza se encuentra muy claramente en el Deuteronomio, articulado enteramente según el formulario de alianza ${ }^{12}$ : la exigencia de Dios (Torá) no es la imposición, más o menos arbitraria, de los caprichos de una divinidad en relación a sus adoradores, sino lo que corresponde a una intervención divina que da a Dios el derecho de esperar respuesta y acogida a sus mandamientos. Es la relación entre soberano y vasallo, muy comprensible si se consideran las relaciones internacionales en el Oriente Medio antiguo, trasportadas a la relación entre Dios y la humanidad. El imperativo es consecuencia del indicativo; aquel se fundamenta en este.

Este esquema está siempre presente en lo que Dios ordena a la humanidad. En sus dos recensiones bíblicas (Dt 5, 6-21; Ex 20, 2-17), las diez palabras empiezan recordando lo que Dios hizo por su pueblo al liberarlos de Egipto y, solamente después, expresan las exigencias que derivan de la acción de Dios que es primero y sirve de fundamento a la exigencia de fidelidad y la respuesta a Dios. "Yo soy el Señor, tu Dios, que te saqué de la tierra de Egipto, de la casa de la esclavitud. Por eso: no tendrás otros dioses» (Ex 20, 2-3). La alianza se expresa literariamente en un género en que primero se recuerda el beneficio recibido (por eso: sección anamnética) y, de esa acción previa de Dios que manifiesta su filantropia, su amor por la humanidad, se siguen las obligaciones que tenemos hacia él (una segunda sección, donde se expresan las exigencias legales que recurren de los beneficios de Dios).

El discurso de alianza corresponde al procedimiento de alianza. Se compone, pues, de una prótasis en el indicativo y de una apódosis en el imperativo. He ahí el díptico estructural de alianza ${ }^{13}$.

12 Cf. N. Lohfink, "Das Hauptgebot. Eine Untersuchung literarischer Einleitungsfragen zu Dtn 5-11», Analecta Biblica, 20 (Biblical Institute Press, Rome 1963). ID., Ascolta, Israele. Esegesi di testi del Deuteronomio. Traducido por E. GatTi (Studi biblici 2; Paideia, Brescia $\left.{ }^{2} 1976\right)$.

13 Prótasis y apódosis son expresiones de la lingüística. Prótasis es la primera parte de un período gramatical; apódosis, la segunda parte, que complementa la primera. 
Js 24, 2-15 puede ser un ejemplo de esa estructura: los vv. 14-15 traen una obligación del pueblo que sería inconcebible para el ambiente cultural bíblico y del Medio Oriente antiguo, si no fuera antecedido por los vv. 2-13, la prótasis histórica. La apódosis con su exigencia de fidelidad se fundamenta sobre la propia historia y, desde ella, adquiere consistencia jurídica y teológica. Otro ejemplo es Dt 32, 4-25: la condenación al exilio (apódosis: vv. 19-25) resulta de la historia de los beneficios no correspondidos que Dios ofreció a su pueblo (prótasis: vv. 4-18).

Lo que vale del procedimiento y del discurso de alianza, vale también de la plegaria hecha basada en la alianza. El pueblo suplica a Dios, confiando en la experiencia primera del amor de alianza (hesed) que Dios le demostró. Cuando el pueblo en el exilio suplica el perdón de Dios, no dice sencillamente: Perdón, Señor, sino, en una oración, recuerda a Dios sus grandes hechos. La oración consta, pues, de dos partes: una prótasis en el indicativo, la sección anamnético-celebrativa de la oración, y una apódosis suplicante, la sección epiclética. En la primera parte de la oración, la comunidad, por su vocero, celebra a Dios, lo alaba, confiesa su acción en la historia, haciendo anamnesis de la fidelidad de Dios y de la infidelidad del pueblo. Esa primera sección pone las premisas lógicas y teológicas de la súplica que será dirigida a Dios en la segunda parte. Esta se denomina epíclesis, del griego $\dot{\varepsilon} \pi \dot{~}+\kappa \lambda \dot{\varepsilon} \sigma ı$ que significa llamado sobre el pueblo que clama ${ }^{14}$. Es una interpelación de naturaleza jurídica, ya que es consecuencia de la prótasis anamnético-celebrativa, pero es una interpelación suplicante, pues la creatura, aunque aliada de este pacto o Alianza, no puede hacer exigencias a Dios ${ }^{15}$. Somos aliados desiguales. La segunda sección se llama ahora anamnético-celebrativa, porque no solo recuerda (anamnesis) lo que Dios hizo por nosotros y nuestro pecado, sino, al recordar, celebra a Dios por su bondad, misericordia y perdón. La articulación entre las dos partes es, en general, expresada por

14 Cf. R. Berger, "Epiklese», en ID., Pastoralliturgisches Handlexikon (Herder, Freiburg - Basel - Wien $\left.{ }^{3} 2005\right)$ 122s.

15 Eso nada tiene a ver con la práctica de grupos neopentecostales que prometen milagros y maravillas que deben (y pueden) ser arrancados de Dios por la fe. La exigencia que eses grupos hacen a Dios está a años-luz de distancia de la promesa manifestada en Cristo que tomó sobre sí nuestras enfermedades y fue un fracasado que murió en la más grande ignominia, abandonado por todos, crucificado por la injusticia, como tantos otros en el decorrer de la historia. 
la partícula lógico-temporal y ahora (אaì vóv) y otras semejantes (por eso, por tanto), que indican la estructuración de la plegaria.

Ese tipo de plegaria es llamado en hebraico todá y el verbo correspondiente es yadáh. Significa confesión, confesar: confesar la fidelidad de Dios en el transcurso de la historia de la salvación, y la infidelidad humana, el pecado. Esos términos hebraicos han sido traducidos al griego por el substantivo eucharistía y el verbo eucharistein ${ }^{16}$. El verbo griego, a su a vez, ha sido traducido al latín como gratias agere, de donde viene nuestro dar gracias.

La plegaria de alianza (todá) puede presentarse en tres modalidades. Una primera modalidad es la dinámica deprecativa simple: consiste en un discurso a Dios con palabras nuestras. Ejemplo bíblico de ese tipo de plegaria de alianza es la todá de $\mathrm{Ne}$ 9, 5-37. Después de un diálogo invitatorio (v. 5), Esdras comienza la sección anamnético-celebrativa reconociendo dos veces: «Tú eres el Señor». Esa doble confesión de fe introduce una contraposición: en el v. 6, en el cielo; en el v. 7-8, en la tierra. Pero, en cuanto la escena en el cielo se encierra con las multitudes de los cielos postrándose delante Dios, el oyente queda en suspenso con relación al desenlace de la escena en la tierra. Cuatro estrofas recuerdan, entonces, lo que sucedió en la tierra entre los aliados de la alianza: al Dios siempre fiel responde la infidelidad del pueblo. Después de esta proclamación de la historia de fidelidad (Dios) e infidelidad (pueblo), hecha delante de Dios, se pasa a la sección epiclética (vv. 32-37). Puede ser que la súplica parezca demasiado modesta, prácticamente reducida al v. 32: que Dios no sea indiferente a su pueblo. Pero, sobre la base de la estructura de la alianza, es un grito imperioso del vasallo, una súplica humilde para que sea reintegrado en la alianza que rompió. Es pedir que Dios vuelva a hacer lo que siempre ha hecho: mirarnos con fidelidad, amor, bondad, benignidad, filantropia, como a la Iglesia oriental le gusta decir ${ }^{17}$.

La segunda modalidad de plegaria de alianza presenta una dinámica deprecativa embolística, es decir: es un discurso a Dios con palabras nuestras y palabras de Dios. Sirva como ejemplo la todá de Ne 1, 5-11. Estando en Susa, en el imperio persa, como copero del rey Artajerjes,

16 La designación eucaristía tiene también la ventaja de sugerir que el memorial de la Pascua del Señor ha sido desde siempre realizado por medio de una todá (memoria y súplica).

17 La palabra filantropía significa literalmente amor a la humanidad. 
Nehemías recibe la noticia de la situación desolada de los sobrevivientes de la deportación que están en Judea. Piensa entonces hacer valer su función de copero para hablar directamente al gran rey sobre sus proyectos. Pero dirigirse al Señor de un imperio en Oriente Medio antiguo no es tan sencillo como se pudiera pensar. Por eso, antes Nehemías se dirige a Dios. Con actitud penitencial, pide a Dios que le dé buen éxito y lo haga ganar la benevolencia de Artajerjes.

Dada la fidelidad de Dios a la alianza y en razón de su misericordia, Nehemías suplica que Dios le ayude a ganar la benevolencia del rey para poder socorrer a sus coterráneos desolados. La novedad de esta plegaria es que, al dirigirse a Dios, Nehemías cita un texto bíblico (cf. v. 8b-9), apto para fundamentar teológicamente el retorno a la Tierra Prometida y la reconstrucción de Jerusalén, Dt 30,1-4. La súplica que trasunta toda la sección epiclética es la reunificación del pueblo y su reconducción a la Tierra de la Promesa. El texto citado es, pues, inserto en el texto como lugar teológico escriturístico para la petición por la reunión del pueblo en su tierra de origen. Ese texto es, de cierta forma, un cuerpo extraño en la estructura de la oración. Por eso, bajo el punto de vista literario, puede

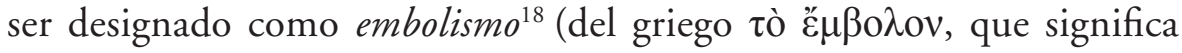
el injerto que se hace en un árbol). La citación formal de las palabras de Dios es un injerto literario que el orante inserta en su formulario de oración por razones teológicas, para fundamentar más explícitamente el pedido que quiere hacer.

Esa segunda modalidad de la dinámica deprecativa (cf. Ne 1, 5-11) tiene, con relación a la primera (cf. Ne 9, 6-37), una mayor complejidad, pero también una mayor riqueza teológica, pues además de la base que la estructura dual de la plegaria de alianza ofrece por su sección anamnética, la dinámica embolística da al pedido una fundamentación teológica. Tratándose de una palabra tomada de la Escritura, ella ya garantiza de antemano que la oración será oída, pues está fundada en la promesa. Dios, al oír de la boca del orante sus propias palabras, se siente como obligado -si se puede decir así- a escuchar la plegaria.

La tercera modalidad es la dinámica semiembolística, la referencia indirecta a las palabras de Dios. Es el caso de la todá (o braká) de Dn 3,

18 Ese es el sentido específico en que Giraudo usa el término; no es el sentido litúrgico común de oración complementaria, como el Líbranos, después del Padre Nuestro, en la liturgia eucarística romana. Cf. C. Giraudo, Num só corpo, 217, n. 9. 
26-45. La sección anamnético-celebrativa (vv. 26-32) recuerda la infidelidad del pueblo. El v. 33 marca claramente la transición para la sección epiclética con un "Y ahora», desde el cual el orante pide por la salvación del resto de Israel. Para subrayar este pedido con más fuerza teológica, evoca la promesa de descendencia numerosa como las estrellas del cielo y las arenas de la playa del mar (v. 36). Pero no hace una citación directa del texto bíblico, sino una referencia indirecta a la promesa. Dios figura en la segunda persona ( $y$ no en la primera) y el destinatario de la promesa en tercera persona (en vez de la segunda). Como no hay citación literal, no se puede hablar de embolismo, sino de semiembolismo, un camino intermedio entre la dinámica deprecativa simple y la embolística. El semiembolismo es, pues, una formulación evocativa del lugar teológico escriturístico.

Las PEs de Oriente y Occidente pertenecen, en general, a la segunda modalidad de plegarias de alianza: de dinámica embolística, en las que se cita, como lugar teológico escriturístico, la narración de la institución de la eucaristía ${ }^{19}$.

\section{LA PLEgARIA EUCARÍSTICA O ANÁFORA}

La primera descripción más completa de una celebración eucarística la encontramos en la eucaristía postbautismal, que Justino nos presenta. Después de describir brevemente el rito bautismal, Justino prosigue:

«A continuación se trae a quien preside la asamblea de los hermanos pan y un cáliz con agua y vino. Tomándolos él eleva la alabanza y gloria al Padre universal, por el nombre del Hijo y del Espíritu Santo, y hace una larga acción de gracias por habernos considerado dignos de recibir de él estos dones. Cuando termina las súplicas y la acción de gracias, todo el pueblo presente expresa su acuerdo, diciendo Amén. Amén es una palabra hebraica que significa $a s i$ sea ${ }^{20}$.

Después, en la misma obra, se encuentra una descripción más completa de la eucaristía. Nos interesa la parte final, cuando habla de la liturgia eucarística. Después de describir la liturgia de la Palabra, añade:

19 Una excepción constituye la anáfora de Addai y Mari, en la cual hay apenas alusión a la institución, pero con clara intención de realizar el memorial de la Pascua del Señor. Cf. C. Giraudo, «Il riconoscimento dell' “ortodossia” della più antica preghiera eucaristica», en Civiltà Cattolica 3753 (2006/IV) 219-233.

20 Justino, Apologia Prima 65,3-4 (SChr 507, 304-305). 
« (...) traen pan y vino y agua, el presidente eleva tanto súplicas como acciones de gracias según su capacidad, y el pueblo expresa su acuerdo diciendo: Amén. Entonces los elementos eucaristizados son distribuidos y recibidos por cada uno; y por medio de los diáconos una parte también es llevada a los ausentes» ${ }^{21}$.

En ambas descripciones de la celebración eucarística, queda claro que la eucaristía en la que participaba Justino se hacía con una anáfora. En la segunda descripción, esta plegaria es descrita por medio de una figura estilística llamada hendiadis: dos substantivos ligados entre sí para designar una unidad. La eucaristía se realiza, pues, por una plegaria que conjuga la súplica con la acción de gracias. Entretanto, en un giro típico de su estilo, Justino cita en primer lugar lo que cabría citar en segundo lugar (hendiadis del tipo hýsteron-próteron literalmente: último [puesto por] primero). Debemos, pues, entender la sucesión de las dos articulaciones mayores de esa plegaria como acción de gracias y súplica, es decir: una todá.

Nada indica que la anáfora de Justino incluyera la narración de la institución. Pero, según el género literario presentado más arriba, en las anáforas puede haber un embolismo, un injerto ${ }^{22}$, que es la citación literal del lugar teológico-escriturístico en se basa el pedido esencial de toda eucaristía: que Dios envíe su Espíritu para transformar los dones del pan y del vino en el cuerpo y la sangre de Cristo, a fin de que, comulgando esos dones, nos transformemos en el cuerpo eclesial de Cristo.

21 Cf. ib., 67,3-5 (SChr 507, 310-311). Justino usa la expresión "elementos eucaristizados" para referirse a los elementos sobre los cuales se ha pronunciado la eucharistia (la acción de gracias).

22 No podemos decir con certeza si la anáfora de Justino contenía o no el relato institucional. Pero existe una razón plausible para pensar que ella todavía no lo poseía. Entre la primera y la segunda descripción de la práctica celebrativa, Justino quiere demostrar que los elementos eucaristizados son verdaderamente «la carne y la sangre de aquel Jesús que se encarnó» (Justino, Apologia Prima 66,2 [SChr 507, 306-307]). Para esa finalidad apela al relato institucional contenido en los Evangelios, pero no hace ninguna mención ni a la descripción que acababa de hacer de la eucaristía, ni a la que hará luego después (cf. ib., 66,3-4 [SChr 507, 306309]). Cf. C. Giraudo, Num só corpo, 233-253. De resto conocemos la eucaristía de la Didaché, 9,1 - 10,7 (SChr 248, 174-183) catecismo cristiano del siglo I. En ella se encuentran evocaciones anamnéticas de la acción de Dios en Cristo y la súplica fundamental de toda eucaristía: la unión de los fieles en el único cuerpo de Cristo. 
El embolismo, injerto de la Palabra de Dios para dar más fuerza al pedido, puede estar tanto en la sección anamnético-celebrativa como en la sección epiclética. Según sea el caso, Giraudo clasifica la anáfora como de dinámica anamnética o de dinámica epiclética, una distinción importante para interpretar las PEs de las diversas familias litúrgicas ${ }^{23}$.

En la anáfora de dinámica anamnética, el presidente, en nombre de la asamblea reunida, alaba a Dios por lo que hizo en la historia de la salvación y, en medio de esa enumeración laudatoria, añade como injerto la narración de la institución. Así cimentado en toda la obra de Dios que culmina en la entrega de Cristo en la cruz y en su resurrección, el celebrante puede entonces hacer el pedido, es decir, pronunciar la epíclesis.

Interesan aquí las PEs de dinámica epiclética, es decir, aquellas en que el embolismo está en la sección epiclética, ya que las PEs romanas siguen ese modelo. El relato de la institución está, por tanto, inserto en medio de la súplica que se hace para que Dios envíe su Espíritu que transforme los dones del pan y del vino en el cuerpo y la sangre de Cristo a fin de que nosotros, al comulgar, nos transformemos en el cuerpo eclesial de Cristo. En el original latino la narración de la institución está, también desde el punto de vista literario y gramatical, íntimamente ligado a la epíclesis sobre los dones, ya sea a través de un pronombre relativo (qui) (PEs I, II, PE del Sínodo Suizo, niños I, II), ya sea a través de una conjunción explicativa (enim) (PEs III, IV, reconciliación II, niños III), ya sea de otra manera adecuada (PE reconciliación I), mostrando claramente que fundamenta el pedido hecho en la epíclesis.

\subsection{La estructura literaria de las plegarias eucarísticas romanas}

En sus estudios C. Giraudo ${ }^{24}$ nos muestra, en primer lugar que es necesario tener presente que la plegaria eucarística es una unidad que comienza

23 C. Giraudo, Num só corpo, analiza 17 anáforas, tanto de la antigüedad (no más usadas) como de la Iglesia Oriental y nuestras actuales. En ese análisis él busca descubrir la estructura literario-teológica de la anáfora y mostrar la teología a ellas subyacente.

24 Cf. C. Giraudo, Num só corpo, 233-412. C. Giraudo, «La struttura letteraria della preghiera eucaristica. Saggio sulla genesi letteraria di una forma. Todà veterotestamentaria. B rakà giudaica. Anáfora cristiana», Analecta Biblica, 92 (Biblical Institute Press, Roma 1981). C. Giraudo, «Eucaristia per la chiesa. Prospettive teologiche sull'eucaristia a partire dalla lex orandi», Aloisiana, 22 (Gregorian University Press - Morcelliana, Roma - Brescia 1989). A nivel de divulgación: ID., Redescobrindo 
en el saludo inicial «El Señor esté con vosotros» y se prolonga hasta el «Amén» final, después de la doxología «Por Cristo, con él y en él...». Son muchas las vicisitudes que han dificultado que los seguidores del rito romano percibieran la unidad de la plegaria eucarística. En primer lugar el uso de prefacios móviles, que varían según la fiesta y el tiempo litúrgico. El canon romano (única plegaria eucarística de la liturgia romana hasta la reforma litúrgica del Vaticano II) empezaba sencillamente en el Te igitur y en este punto, durante mucho tiempo, constaba en los misales: Incipit canon actionis que se podría traducir por «[Aquí] empieza la norma de la acción [litúrgica]». La interrupción de la unidad era todavía más acentuada al poner una escena del Calvario en la página frente al inicio del canon (ahora de la PE I). La idea ha surgido de los copistas medievales que solían ornamentar con iluminuras las letras iniciales de un texto. Ahora bien, el canon romano empezaba justamente con una «T», de Te igitur, que sugería fácilmente una cruz y de ahí la escena de la crucifixión. La invención ha tenido tanto éxito que hasta hoy encontramos en nuestros misales el resultado de la evolución de esa práctica de los copistas medievales. Con la introducción de las nuevas PEs II e IV, que tienen prefacio propio y, en el segundo caso, inseparable del texto restante, se estableció la confusión en las cabezas, especialmente por el hecho de el prefacio de la PE II puede ser sustituido. Se piensa entonces que también los otros prefacios son separables y la plegaria eucarística empieza solo después del canto del Santo. Si tuviéramos en mente la tradición oriental, sabríamos que la plegaria eucarística es una totalidad. Existe una continuidad desde el prefacio (y todavía antes: desde el diálogo invitatorio) hasta el fin. No se puede simplemente tomar un prefacio y acoplarlo a cualquier plegaria eucarística, fuera de aquellas que no tienen prefacio propio (PE I - Canon Romano; PE III; por concesión también la PE II $)^{25}$.

a eucaristia. Traducido por F. TABORDA (Loyola, São Paulo $\left.{ }^{3} 2005\right)$. Original italiano: Conosci davvero l'eucaristia? (Liturgia e vita; Edizioni Qiqajon, Magnano, BI 2001) ID.: Admiração eucarística: para uma mistagogia da missa à luz da encíclica Ecclesia de Eucharistia. Traducido por O. MoreIra (Loyola, São Paulo 2008) 95-113. Original italiano: Stupore eucaristico. Per una mistagogia de la messa alla luce dell'enciclica Ecclesia de eucharistia (Libreria Editrice Vaticana, Città del Vaticano 2004).

25 La tercera edición típica del Misal Romano de Pablo VI cambió completamente la configuración gráfica de las PEs. En las dos que no poseen prefacio propio (PEs I e III) después del título viene el diálogo invitatorio y, a seguir, la rubrica "Se sigue el prefacio a ser escogido según las rubricas y que concluye: Santo, Santo, 
Otro factor del rito romano que hace difícil para nosotros percibir la unidad de la anáfora son los cuatro Per Christum Dominum nostrum (Por Cristo nuestro Señor) ${ }^{26}$ que fragmentan el canon romano en diversos conjuntos de oraciones que parecen servir de mera moldura a la narración de la institución. Aunque sean facultativos en el Misal de Pablo VI $y$, por ende, estén entre paréntesis, siguen presentes como resquicios de una comprensión que insiste en perdurar.

Toda anáfora consta de nueve elementos que se suceden y encadenan, con lógica propia en las diversas tradiciones litúrgicas, entre el diálogo invitatorio y el amén final. Ellos son, en el orden seguido en las anáforas romanas: prefacio, Santo, post-Santo, epíclesis sobre los dones, relato institucional, anamnesis, epíclesis sobre los comulgantes, intercesiones, doxología. Los nueve elementos se distribuyen en las dos secciones de la plegaria eucarística, pero su secuencia y distribución en las secciones varían según la familia litúrgica ${ }^{27}$. Hay también anomalías o excepciones

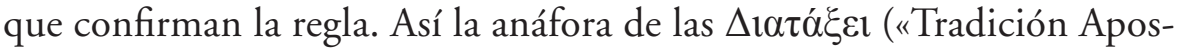
tólica») no tiene Santo ni intercesiones; la anáfora de Addai y Mari no contiene el relato; el canon romano desconoce el post-Santo.

Hechas estas consideraciones generales sobre la estructura de las PEs romanas, pasemos al análisis de los nueve elementos en el orden en que ahí se encuentran.

3.2. La composición las plegarias eucarísticas romanas

\subsubsection{Diálogo invitatorio}

Todas las PEs empiezan por un diálogo que invita la asamblea a iniciar la acción de gracias a Dios. Por eso se denomina diálogo invitatorio. En eso sigue la práctica de la oración sinagogal judaica que presumiblemente ya se encuentra en $\mathrm{Ne} 9,5$.

Santo» (es transcrito el texto completo del Santo) y solo entonces viene Te igitur, respectivamente Vere sanctus.

26 Después de los párrafos oracionales Communicantes, Hanc igitur, Supplices y Memento de los difuntos.

27 Ver el esquema que pone lado a lado la estructura de las anáforas siro-occidental, siro-oriental, alejandrina y romana. Cf. C. Giraudo, Num só corpo, 252. 
El primer miembro del diálogo es un saludo: El Señor esté con vosotros, cuya respuesta es $Y$ con tu espiritu. Esto tiene un sentido dialogal muy profundo: el presidente desea al pueblo reunido que el Señor esté con la asamblea, y el pueblo responde deseando lo mismo para el presidente. Tanto el presidente como la asamblea tienen el Señor para transmitirlo y desearlo los unos a los otros. El pueblo recibe y retribuye el saludo.

Los Padres de la Iglesia en sus mistagogías a veces iban todavía más lejos y en la respuesta de la asamblea leían la palabra espíritu en una doble óptica: con minúscula, significando la dimensión espiritual del ser humano, apta a ser un templo para el Señor; con mayúscula, evocando el Espíritu Santo que el presidente había recibido en su ordenación, cuya posesión debía ser como que reavivada al empezar la gran plegaria que la Iglesia dirige al Padre a través del ministerio de aquellos a quienes el Espíritu ha sido dado para presidir la comunidad ${ }^{28}$.

Una vez que la presencia del Señor nos une, podemos proseguir. Levantemos el corazón. Lo tenemos levantado hacia el Señor. Aunque toda y cualquiera oración exija de nosotros una actitud correspondiente a lo que estamos haciendo: vueltos hacia Dios, la PE de modo especial. Por eso no extraña que la Iglesia use al comienzo de ella esta expresión originaria de la mística judaica de la orientación del corazón hacia Dios, orientación que debe traspasar toda nuestra vida, pero especialmente este momento cuando, unidos a Cristo, nos dirigimos a Dios en Espíritu Santo para el acto supremo de culto.

Los Padres de la Iglesia son muy conscientes de la importancia de que se responda con verdad y sinceridad a esta invitación. Si decimos que «tenemos el corazón levantado hacia el Señor», que él esté de hecho en Dios y no en otra parte. Cesario de Arles (†543), obispo con fina sensibilidad pastoral, haciendo una mistagogía de la invitación levantemos el corazón, dice en uno de sus sermones:

"Cuando, pues, la mayor parte del pueblo, peor todavía, casi todos, salen de la iglesia después de la proclamación de las lecturas, ‘a quienes el sacerdote dirá: Levantemos el corazón? O, ¿`cómo pueden responder que tienen levantado el corazón, cuando descienden hacia abajo, hacia la plaza, tanto con el cuerpo como con el corazón? O, ¿̇de qué modo

28 Cf. Teodoro de Mopsuestia: Homilía 15, 36-38, en Théodore de Mopsueste: Homélies catéchétiques (Migne - Brepols, Paris 1996) 261. 
podrán aclamar, al mismo tiempo con temblor y alegría: Santo, Santo, santo, bendito el que viene en nombre del Señor? ${ }^{29}$.

Una vez asegurado que tenemos el corazón levantado hacia el Señor, viene el tercer elemento del diálogo invitatorio, la invitación a la acción de gracias: Demos gracias al Señor nuestro Dios. Dar gracias en el sentido de confesar las maravillas que Dios hizo por nosotros en la historia de la salvación y confesar nuestra infidelidad. La asamblea responde: Es justo y necesario. Es justo, porque, por el bautismo-confirmación, Dios nos hizo dignos de ponernos en su presencia y realizar el servicio divino, celebrar la liturgia (cf. PE II, anamnesis). Es necesario, porque reconocer los beneficios recibidos de Dios y nuestra ingratitud no solo es una cuestión de justicia hacia Dios como es, por la misma bondad del Señor, la realidad misma de la salvación, nuestra justificación. Dios no necesita nuestra acción de gracias, sino somos nosotros que tenemos necesidad de acoger sus beneficios y reconocerlos.

Con estas disposiciones de espíritu, la asamblea está en condiciones de empezar el núcleo de la celebración de los santos misterios con la plegaria eucarística.

\subsubsection{Sección anamnético-celebrativa}

En las PEs romanas, esta primera sección se compone de tres elementos: el prefacio, el Santo y el post-Santo.

\section{a) Prefacio}

Solemos llamar de prefacio la primera parte de la acción de gracias anafórica. No siempre ha sido asi ${ }^{30}$. Todo indica que la palabra designó primeramente toda la plegaria eucarística, pues en el lenguaje sacro de la antigüedad praefari se refería a una oración ligada al sacrificio. Así en el lenguaje cristiano la palabra praefatio pudo denominar la solemne plegaria que se eleva a Dios delante de la comunidad reunida ${ }^{31}$. En este caso,

29 Cesario de Arles, Sermo 73, 2 (SChr 330, 192-193).

30 En Cipriano de Cartago, De oratione Dominica 31 (PL 4, 539) encontramos el término prefacio para designar el diálogo invitatorio. En este caso, prefacio tiene semejanza con el uso hoy habitual de la palabra en el lenguaje profano.

31 Cf. A. J. Jungmann, Missarum sollemnia. Eine genetische Erklärung der römischen Messe. Bd. 2: Opfermesse (Herder, Wien 1948) 129-130. Traducción española: El 
cabe al prefijo prae un sentido espacial como, en praelectio (prelección = lectura delante de un auditorio), praedicatio (predicación = dicción delante de una comunidad reunida). Da a entender una acción que acaece en el espacio, delante de alguien, y no solo en el tiempo, antes de otra acción $^{32}$. Como hoy la palabra es usual para designar aquella parte de un libro que viene antes del texto propiamente dicho, y hay quienes lean el libro sin leer el prefacio y no por eso juzgan perder algo sustancial e imprescindible, así es posible pensar lo mismo del prefacio de la plegaria eucarística. Pero no es así. El prefacio es parte integrante, indispensable, pues en él se expresa el motivo de la alabanza. En la liturgia romana eso se da casi exclusivamente en el prefacio, pues los post-Santos solo aparecen en las PEs post-Vaticano II y son raros los post-Santos más extensos y densos, o -para ser más exacto- solo cabe esa calificación el post-Santo de la PE IV. Si es así, tanto más importante se hace el prefacio.

El prefacio es, pues, una oración proclamada delante de Dios y delante de la asamblea reunida y en su nombre, para la glorificación de Dios. En las liturgias orientales, en general, el prefacio y el post-Santo son de una grande riqueza. Toda la historia de la salvación es repasada delante los ojos admirados del orante, tal como tenemos en la PE IV, inspirada cuanto al contenido en anáforas orientales (Basilio y Santiago). Pero la regla en la liturgia romana es un prefacio móvil, separado de la restante anáfora, y que acentúa el sentido de cada tiempo litúrgico y de cada fiesta.

En el prefacio se pueden distinguir tres partes: la invitación a la alabanza, el motivo de la alabanza, la transición al canto del Santo. En la invitación a la alabanza el elemento principal son los verbos que expresan glorificación de Dios (dar gracias, alabar, cantar himnos, glorificar, confesar, bendecir...). La liturgia romana, entretanto, es bastante sobria en el uso de esos verbos, como, además, en términos generales, es propio del espíritu de esa familia litúrgica. La parte central del prefacio expresa la razón que lleva la asamblea reunida a entonar himnos a Dios. En la liturgia romana, es especialmente importante esta parte, por eso de los prefacios móviles, según el tiempo litúrgico o la solemnidad/fiesta del día. Con eso, traen en breves palabras el motivo especial que reúne la comunidad en aquella fecha. Por fin, el prefacio concluye conduciendo

sacrificio de la Misa: Tratado histórico-litúrgico (BAC 68; Editorial Católica, Madrid $\left.{ }^{3} 1959\right)$.

32 Cf. A. J. Jungmann, Missarum sollemnia II, 130, n. 42. 
al canto del Santo. En esa transición trasparece el sujeto que eleva su alabanza: la asamblea reunida, en comunión con toda la Iglesia de la tierra y con la Iglesia de los bienaventurados, santos y ángeles, cuya alabanza se entonará a continuación.

El prefacio culmina en la introducción al himno del Santo, según la práctica de determinadas oraciones usadas en la sinagoga ${ }^{33}$. El Santo es el canto de los ángeles. En el Misal de Pío V, como en muchas liturgias orientales, la transición al Santo puede, a veces, nombrar explícitamente los nueve coros angélicos o parte de ellos: ángeles, arcángeles, tronos, dominaciones, principados, potestades, querubines y serafines. Por la lógica del contexto el Santo debería ser siempre cantado en todas las celebraciones eucarísticas. Debería ser el canto por excelencia en nuestras liturgias, porque, a través de él nos unimos al canto de los bienaventurados.

La transición del prefacio al Santo expresa la teología del Santo. En ese momento, tomamos conciencia de algo fundamental en la celebración de la eucaristía: la unión de las dos asambleas. Estamos reunidos para alabar a Dios y para suplicar. Pero solo podemos hacerlo a ratos. No podemos pasar el día todo reunidos en la alabanza y la súplica a Dios. Es verdad que la vida cristiana toda es un acto de culto a Dios. Pero no por eso la alabanza permanente deja de ser un ideal que solo puede ser realizado por aquellos que son como los profesionales de la alabanza, siempre delante de y junto a Dios porque ya están en la visión beatífica, en la comunión plena y definitiva con Dios: los ángeles, los santos, todos los que murieron en la amistad de Dios, aunque no hayan podido explicitar su fe. Ellos son hermanos y hermanas nuestras. Nos unimos a ellos en la misma alabanza, para que completen la insuficiencia de nuestro canto. En la anáfora de Santiago, la anáfora de la Iglesia de Jerusalén, toda la creación es incluida en la alabanza de Dios. Y una alusión a la Jerusalén celeste sugiere que la comunidad de la Jerusalén terrestre se une a sus antepasados en la fe, la Jerusalén celeste, explícitamente mencionada, para entonar el himno de alabanza ${ }^{34}$. Hoy en día, la llamada anáfora zairense expresa, como todas las anáforas, la unión de la asamblea de la tierra con los ángeles y los santos, pero -fiel a la tradición africana del culto

33 En la himnografía cristiana, se pueden citar también el Te Deum que trae embutido el canto de los serafines.

34 Cf. C. Giraudo, Num só corpo, 286. 
a los antepasados- añade explícitamente su unión con los difuntos en la misma alabanza a Dios, porque, con la asamblea reunida, los ángeles y los santos, también los ancestrales están delante de Dios, en la plena comunión con él ${ }^{35}$. Es muy consolador para una persona que ha perdido un ser querido saber que, en el momento de la celebración eucarística -y máxime en el canto del Santo-, ella se puede unir verdadera y realmente a esa persona en la única alabanza a Dios por medio de Cristo en el Espíritu Santo.

\section{b) Santo}

En el momento del Santo se hace real y sensible la unión de las dos asambleas: la de la tierra y la del cielo, y de esta forma la dimensión escatológica de la eucaristía. Ambas asambleas están, en este momento, en actitud de adoración, acción de gracias, alabanza. Para expresar esa unión, aprendiendo de la tradición sinagogal judaica, la Iglesia emplea un canto que reproduce dos textos bíblicos, donde se narra la alabanza de los seres celestiales. Es un canto compuesto de dos partes. La primera proclama la santidad de Dios, con los serafines de la visión de Isaías en el templo (Is 6, 3); la segunda parte, en la tradición judaica, repetía el canto de los seres celestiales en Ez 3, 12: «iBendita sea la Gloria del Señor desde su morada! » ${ }^{36}$. He aquí el texto de la Tffillá festiva, recitada en la sinagoga cuando el primer día del mes (la neomenia) cae en día sábado:

«Una corona te dan las multitudes de allá arriba con las asambleas acá abajo; juntas todas te triplican la proclamación de la santidad, como ha sido dicho por medio de tu profeta: Y gritaban el uno al otro y decían: Santo, santo, santo es el Señor de los Ejércitos; ¡llena está toda la tierra de su gloria! Entonces [otros], haciendo escuchar una voz de estrépito grande, sublime y fuerte y elevándose frente a ellos, [...] dicen: ¡ Bendita sea la gloria del Señor desde su Lugar! »37.

Aquí se trata claramente de Ez 3, 12. La forma eclesial «Bendito el que viene en nombre del Señor», que sustituye el texto de Ezequiel usado

35 Cf. C. Giraudo, Num só corpo, 408.

36 Cf. las dos bendiciones que preceden al Oye, Israel. En ellas al canto del Santo por los serafines se añade el canto de las ruedas angélicas (aOfanním) del trono-carro divino y de los cuatro vivientes (Hayyót) que lo tiran: «ßBendita es la gloria del Señor desde su Lugar! ». Lo mismo vale de la Tefillá de la neomenia que cae en sábado. Cf. los textos y comentarios en C. Giraudo, Num só corpo, 214-225.

37 Giraudo: Num só corpo, 220 [subrayado mío]. 
en la sinagoga, ya es una relectura cristiana desde la aclamación mesiánica a Jesús, en su entrada en Jerusalén: «iBendito el que viene en nombre del Señor! ¡Hosanna en lo más alto de los cielos!» (Mt 21, 9; cf. Mc 11, 9 y Lc 19, 38). La primera parte tiene su inspiración en el Sal 119, 25 s, donde la aclamación se refiere a la procesión solemne que se dirige al Templo. Pero el que viene (también sin añadir en nombre del Señor) se tornó designación del Mesías ${ }^{38}$. En ese lugar del salmo se encuentra también la palabra Hosanna que significa ayuda, por favor, socorre. Con eso la aclamación se transforma en homenaje al Mesías Jesús, en quien Dios se ha dignado acercarse a nosotros ${ }^{39}$.

Considerando la modificación de Ez 3, 12, podríamos reconocer que, en el momento del Santo, no solo nos unimos a los ángeles en su cántico de alabanza al Padre, sino también ellos se unen a nosotros en una aclamación al Señor Jesús, el Mesías enviado por el Padre para nuestra salvación.

En latín la forma venit (Benedictus qui venit in nomine Domini) contiene una ambigüedad, pues gramaticalmente puede ser tanto presente del indicativo como pretérito perfecto. En el segundo caso, la aclamación se referiría a la encarnación. En cuanto está en el presente del indicativo, la aclamación se refiere igualmente al pasado y al futuro, ya que aquel que vino es el mismo que viene y vendrá. Así se profesa la constante presencia de Cristo a los miembros de su Cuerpo hasta que el Señor se manifieste plenamente en la parusía ${ }^{40}$.

\section{c) Post-Santo}

Después del canto del Santo, continúa la alabanza y la acción de gracias a Dios, retomando algunas palabras del canto como eslabón de unión con lo que ha precedido el canto. En general la palabra clave retomada es Santo; a veces es (también) Bendito ${ }^{41}$. Ese trozo de la plegaria eucarística es identificado como post-Santo, la alabanza que se sigue después del canto del Santo, iniciando con palabras como: Santo eres en verdad.

\footnotetext{
38 Cf. J. Schneider, ěp $\chi 0 \mu \alpha 1$, en ThWNT 2, 664-672 (aquí: 666s).

39 Cf. A. J. Jungmann, Missarum sollemnia, II, 166, n. 42.

40 Cf. A. J. Jungmann, Missarum sollemnia, II, 166-167.

41 En la anáfora de Marcos, el encadenamiento se hace por la palabra lleno, resultando en el post-Santo epiclético (cf. Giraudo. Num só corpo, 367-368).
} 
Tradicionalmente la liturgia romana no conocía un post-Santo, ya que en el canon romano (PE I), la única plegaria eucarística usada en la liturgia romana del siglo IV al siglo XX, no tiene post-Santo. Las PEs introducidas con la reforma litúrgica del Vaticano II han adoptado esa estructura que se encuentra en las otras familias litúrgicas. En ese sentido se destaca la PE IV, donde se puede observar claramente que el post-Santo continúa el prefacio, hablando de la caída, de la alianza y sus renovaciones y, por fin, de la cristología histórica (encarnación, vida, muerte, resurrección y ascensión de Jesús, culminando con Pentecostés). En las otras PEs post-Vaticano II, el post-Santo es más resumido y más pobre, pero suele estar siempre presente. Así en la PE II, en la simplicidad de la expresión fuente de toda santidad se resume toda la acción salvífica de Dios por el Espíritu Santo que culmina en la revelación en Cristo. En la PE III, el post-Santo resume la historia de la salvación en la obra santificadora de la Trinidad: por Cristo en el Espíritu el Padre reúne su Iglesia, unificada por la unidad de la Trinidad.

\subsubsection{Sección epiclética}

Los restantes seis elementos de una anáfora constituyen en la PE romana, la sección epiclética.

\section{a) La doble epiclesis}

En una metáfora geométrica podríamos concebir la PE como una elipse, que tiene su origen desde dos polos: la doble epíclesis y el bloque relato de la institución-anamnesis. Como en una elipse no es posible decir que un polo sea más importante que el otro, o que el uno viene antes del otro. O tenemos dos polos y se genera una elipse, o no hay elipse. Así también en la PE: o hay anamnesis y epíclesis y se constituye una anáfora, o no hay PE.

En la anáfora romana, la sección epiclética empieza con el cuarto elemento en la estructura, la epíclesis sobre los dones, la súplica para que Dios, por el envío del Espíritu Santo, transforme los dones del pan y del vino, que hemos traído y presentamos, en el cuerpo y la sangre de Cristo. Ahí es invocado el Espíritu Santo, porque es en el Espíritu que se realiza la liturgia eucarística y todo otro sacramento, es en el Espíritu que se construye el cuerpo de Cristo, la Iglesia. La teología occidental 
tiene como una anteojera que, con todo, impide identificar la acción imprescindible del Espíritu Santo.

Dentro de esa lógica y talvez como una de las causas del olvido del Espíritu en la teología occidental, el canon romano (PE I) no hace ninguna referencia al Espíritu Santo. Entretanto, los conocedores de la gran tradición eran capaces de descubrir el Espíritu Santo en el canon romano, aunque no mencionado expresamente. Es el caso del mismo Pedro Lombardo, obispo de París (siglo XII), quien escribió el Libro de las Sentencias, obra de inmensa importancia por haberse tornado, desde entonces, el manual de teología de toda la Edad Media. Él sabía todavía que el Espíritu Santo actúa en la eucaristía, porque conocía la tradición oriental, aunque no encontrara en el canon romano la referencia al Espíritu. En la reforma litúrgica del Vaticano II, la Iglesia redescubre que el Espíritu Santo es fundamental en la eucaristía. Y así las nuevas PEs pasan a usar una epíclesis explícita, en que explícitamente se suplica por el Espíritu Santo.

Pero esta súplica, aunque en la anáfora romana esté separada de la súplica por el Espíritu Santo sobre los comulgantes, no puede ser considerada aisladamente. Ella llega a término con la súplica por el Espíritu Santo sobre la asamblea reunida para recibir el cuerpo y la sangre de Cristo (epíclesis sobre los comulgantes). En la liturgia romana, la doble epíclesis por así decírselo se rompe para acoger en su interior el relato institucional con la anamnesis. Visto en esa perspectiva a la luz de las anáforas orientales se entiende que el pedido para que el Espíritu transforme los dones en el cuerpo sacramental de Cristo tiene por finalidad que nosotros, al comulgar, seamos transformados en el cuerpo eclesial de Cristo.

La unidad de las dos epíclesis aparece más claramente en textos de la liturgia oriental. En la recensión alejandrina de la anáfora de Basilio las dos epíclesis no solo están unidas, sino entrecruzadas:

«Y te pedimos e invocamos, buen filántropo, Señor, nosotros pecadores e indignos siervos tuyos -y te adoramos-, para que, por el beneplácito de tu bondad, venga tu Espíritu Santo sobre Nosotros, tus siervos, y sobre estos tus DoNEs presentados, y [los] santifique y [los] manifieste como [misterios] santos de los santos, y haga con que este PAN se convierta en el santo cuerpo del mismo nuestro Señor y Dios y salvador Jesucristo, para la remisión de los pecados y para la vida eterna para aquellos que de el participan, y que este cálız [se torne] 
la preciosa sangre de la nueva alianza del mismo nuestro Señor y Dios y salvador Jesucristo, para la remisión de los pecados y para la vida eterna para aquellos que de el participan; y haznos dignos, Soberano, de participar de tus santos misterios, para la santificación del alma, del cuerpo y del espíritu, a fin de que nos transformemos en un solo cuerpo y en un solo espíritu y encontremos parte y tengamos herencia con todos los santos, que, desde cuando estaban en el mundo, han sido de tu agrado ${ }^{42}$.

Reduciendo el texto a su esquema básico, resulta:

Envía tu Espíritu sobre NOSOTROS y sobre los DONES presentados para que transforme los DONEs en el cuerpo sacramental a fin de que, comulgando, NOsOTRos seamos transformados en el cuerpo eclesial.

Ese texto manifiesta claramente la unidad que existe entre la transformación de los dones y nuestra transformación. Gráficamente ${ }^{43}$ : Envía tu Espíritu sobre nosotros y sobre los Dones presentados

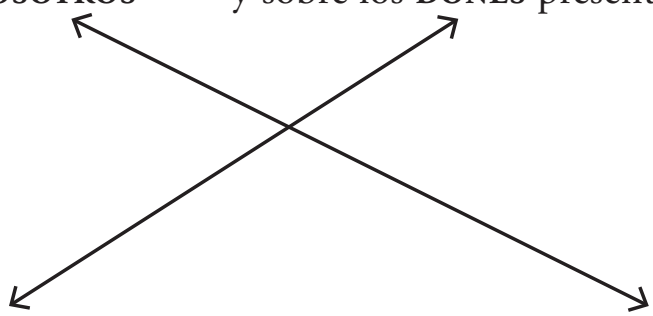

para que transforme los Dones a fin de que, comulgando, Nosotros en el cuerpo sacramental seamos transformados en el cuerpo eclesial

La figura literaria de elementos entrecruzados se llama quiasmo. Pero, en el caso de la epíclesis de la anáfora de Basilio, el quiasmo no es solo literario, sino también teológico. Y es teológico, porque explicita la finalidad de la eucaristía. La eucaristía no ha sido instituida simplemente para transformar el pan y el vino en el cuerpo y la sangre de Cristo, es decir: para que Cristo se haga presente entre nosotros. Cristo está presente de innumerables formas en la liturgia y en la vida. La Constitución Litúrgica del Vaticano II explicita algunas formas litúrgicas de la presencia de Cristo:

\footnotetext{
42 C. Giraudo, Num só corpo, 303 [subrayado mío].

43 C. Giraudo: Num só corpo, 307.
} 
«Para realizar una obra tan grande [la obra de la salvación], Cristo está siempre presente a su Iglesia, sobre todo en la acción litúrgica. Está presente en el sacrificio de la misa, sea en la persona del ministro, "ofreciéndose ahora por el ministerio de los sacerdotes el mismo que entonces se ofreció en la cruz" [Concilio de Trento], sea sobre todo bajo las especies eucarísticas. Está presente con su fuerza en los sacramentos, de modo que, cuando alguien bautiza, es Cristo quien bautiza [Santo Agostinho]. Está presente en su palabra, pues cuando se lee en la Iglesia la Sagrada Escritura, él quien habla. Está presente, por último, cuando la Iglesia suplica y canta salmos, el mismo que prometió: "Donde están dos o tres congregados en mi nombre, allí estoy yo en medio de ellos" (Mt 18, 20)» ${ }^{44}$.

Menos de dos años después de la promulgación de la Constitución Litúrgica, Pablo VI, en su encíclica Mysterium fidei (3 de septiembre de 1965), recordó lo que el Concilio había dicho y complementó la lista con otras dimensiones y formas extralitúrgicas de la presencia de Cristo: presente en el pobre y necesitado (cf. Mt 25, 40); en el anuncio del Evangelio; en los pastores en su función de gobernar la Iglesia; en nuestros corazones, donde habita por la $\mathrm{fe}^{45}$.

Si es así, la eucaristía no es necesaria para crear presencia de Cristo, pues él ya está ahí realmente presente de muchas maneras. La finalidad de la eucaristía es transformarnos a nosotros en el cuerpo eclesial de Cristo a través de la comunión en el cuerpo sacramental. Por eso, la eucaristía es el sacramento de la unidad. Justamente eso queda muy claramente expreso en la epíclesis de la anáfora de Basilio.

Esas dos transformaciones, la del pan y del vino en cuerpo y sangre de Cristo y la de la asamblea litúrgica en cuerpo eclesial de Cristo, están íntimamente unidas. La primera transformación la teología latina ha designado con el término transubstanciación que el Concilio de Trento declara ser una forma conveniente y apropiada de expresar lo que sucede con el pan y el vino en la celebración eucarística (cf. DH 1642 e 1652). Significa que la substancia ${ }^{46}$ del pan y del vino es sustituida por la substancia del cuerpo y de la sangre de Cristo. Es decir: la realidad última de

44 Concilio Vaticano II, Sacrosantum Concilium, 7 [subrayado mío]; ahora DH 4007.

45 Cf. Pablo VI, Mysterium fidei, 35-41.

46 Substancia es un término oriundo de la filosofía aristotélica para designar la realidad última de una cosa. 
ese pan y de ese vino ya no es ser pan y vino, sino ser cuerpo y sangre de Cristo, aunque los sentidos nos digan lo contrario, porque los sentidos no alcanzan la substancia, sino solo los accidentes.

En una intuición genial, un teólogo poco conocido del siglo XV, el carmelita Tomás Valdense $(\dagger 1430)$ define la Iglesia como «el cuerpo místico de Cristo, en el cual cada cristiano se transubstancía por la recepción del bautismo y de la sagrada eucaristía» ${ }^{47}$. Él expresa, sin que se base en la tradición anafórica, el resultado de la segunda epíclesis. Ser cuerpo de Cristo no es mera metáfora para nuestra comunión con Cristo; es una realidad, nuestra realidad última como Iglesia.

Pero, como la presencia real de Cristo en la eucaristía no debe ser aislada en relación a las otras maneras de presencia, aunque la presencia eucarística sea substancial y, por eso, sea la presencia por excelencia, tampoco la transubstanciación del pan y del vino en el cuerpo y la sangre de Cristo puede ser aislada en relación a otras transformaciones que se desencadenan desde el Cenáculo.

Benedicto XVI lo expresó magníficamente en su homilía en la XX Jornada Mundial de la Juventud, en Köln (Alemania), el 21 de agosto de $2005^{48}$. La primera transformación que el Papa acentúa y puede ser considerada la fuente de las otras es la crucifixión. Exteriormente es violencia brutal; por su aceptación se hace un gesto del amor que se da. ¡La violencia se transforma en amor, la muerte en vida! Por transformar la muerte en amor, la muerte está superada desde dentro y la resurrección ya está presente en ella. Esa primera transformación arrastra con ella las otras. Pan y vino se hacen cuerpo y sangre de Cristo entregados por nosotros. Pero la transformación no se detiene ahí. El cuerpo y la sangre de Cristo nos son dados para que nosotros mismos seamos transformados, seamos consanguíneos de Cristo. La finalidad última de todas esas transformaciones, a su vez, es la transformación del mundo hasta que Dios sea todo en todos.

47 Ecclesia... corpus Christi mysticum, in quod transsubstantiantur singuli Christiani per suptionem baptismatis, \& Sacrae Eucharistiae (Thomas NetTer: Doctrinale Antiquitatum Fidei Catholicae Ecclesiae, t. 1, 1. 2, cap. 16 [ed. 1757, p. 319], cit. en C. Giraudo: Num só corpo, 312 [subrayado mío]).

48 Cf. Benedicto XVI. Homilía en la XX Jornada Mundial de la Juventud [en línea] (Colonia 2005) [Fecha de consulta: 21 octubre 2011)]. Disponible en: http://www.vatican.va/holy_father/benedict_xvi/homilies/2005/documents/ hf_ben-xvi_hom_20050821_20th-world-youth-day_sp.html 
Esa reflexión de Benedicto XVI se inscribe dentro de la gran tradición anafórica y la amplía, revelando claramente la tensión escatológica de la eucaristía en vista de la plenitud del cosmos en Dios, cuando Dios será todo en todos (cf. 1Cor 15, 28).

A pesar de que, en la liturgia romana, las dos epíclesis estén separadas la una de la otra, es necesario tener presente su unidad y observar que la separación entre ellas no es división, ya que entre ambas epíclesis, uniéndolas indisociablemente, se incluye justamente el lugar teológico escriturístico de la plegaria eucarística, la fundamentación última del pedido. ¿Por qué suplicamos el Espíritu Santo sobre los dones? Porque Jesús mandó que hiciéramos lo que él ha hecho: «Haced esto (la señal del pan y del vino) en conmemoración mía (en memorial de mi muerte y resurrección) ». Así, antes de completar la súplica por el Espíritu Santo, recordamos lo que nos da derecho (¡el derecho de alianza!) a hacer esa súplica: la orden de reiteración, el memorial que ofrecemos al Padre según el mandato de Jesús.

\section{b) El bloque relato - anamnesis}

Relato de la institución y anamnesis constituyen un bloque unitario. Es lo que se puede ver claramente en la anáfora de las Constituciones Apostólicas (siglo V):

«Al acordarnos, por tanto, de todo lo que por nosotros soportó, te damos gracias, Dios omnipotente, no tanto cuanto debemos, pero tanto cuanto podemos, y cumplimos su precepto. Porque en la noche en que era entregado [...] "Haced esto en conmemoración mía. Pues toda vez que comáis de este pan y bebáis de este cáliz, anunciareis mi muerte, hasta que yo venga". Al acordarnos, pues, de su pasión y muerte, y de la resurrección de entre los muertos y del retorno a los cielos y de su futura segunda venida cuando vendrá con gloria y poder para juzgar los vivos y los muertos y retribuir a cada uno según sus obras, te ofrecemos, rey y Dios, según su precepto, este pan y este cáliz, dándote gracias por medio de él, porque nos tornaste dignos de estar delante ti y te servir por el sacerdocio» ${ }^{49}$.

Esquemáticamente:

Al acordarnos de todo lo que por nosotros soportó... (comienzo de la anamnesis)

49 Constituciones Apostólicas VIII, 12, 35-38 (SChr 336, 196-199) [Subrayado mío]. Ver también la anáfora de Serapión, C. Giraudo: Num só corpo, 349. 
Relato de la institución

Al aCORDARnos de su pasión y muerte, y de la resurrección... (retomada de la anamnesis)

En este caso es como si la anamnesis acogiera en su seno el relato institucional. Considerando que la anáfora primitiva muy probablemente no contenía la narración de la institución que le fue posteriormente añadida a modo de embolismo ${ }^{50}$, es válida la hipótesis de que la anamnesis, expresión del memorial ofrecido al Padre, haya atraído la narración del acontecimiento que le dio origen: la última cena en el Cenáculo.

Para nosotros, occidentales, parece muy curioso tomar conocimiento de que hay una anáfora, aún en uso en una Iglesia cristiana, que no contiene el relato de la institución. Y en la antigüedad no faltaban anáforas, después caídas en desuso, que prescindían del relato institucional o lo contenían solo parcialmente (solo las palabras sobre el pan o solo las palabras sobre el cáliz) ${ }^{51}$.

El ejemplo mayor es de la anáfora de los Apóstoles Addai y Mari, usada en la Iglesia Asiria de Oriente (la Iglesia del actual Irak). Es la anáfora más antigua todavía en uso. El hecho de no presentar el relato de la institución llevaba el occidental a preguntar si esa Iglesia, de hecho, celebraba válidamente la eucaristía. En 2001, el Secretariado para la Unidad de los Cristianos, en un documento firmado conjuntamente por la Iglesia Asiria de Oriente y la Iglesia Caldea (unida a Roma) y aprobado por Juan Pablo II, ha reconocido la validez de la eucaristía celebrada con la anáfora de Addai y Mari, fundamentando el reconocimiento en el hecho de que esa anáfora hace el memorial ${ }^{52}$, aunque no cite directamente las palabras de Jesús en la última cena. Posiblemente era así que los primeros cristianos celebraban la eucaristía: a través de una plegaria

50 Cf. Giraudo: Num só corpo, 233-250.

51 Cf. C. Giraudo, Eucaristia per la chiesa, 349-359.

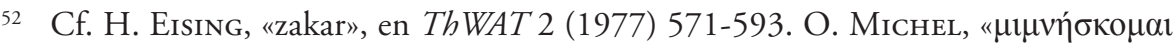
$\kappa \tau \lambda$.», en ThWNT 4 (1942) 678-687. H.-J. FABRY, "Anamnesis. III. Biblisch», en LThK $K^{3}$ 1, 590-591. B. Neunheuser, Memorial, en D. Sartore - A. M. Triacca (org.) Dicionário de Liturgia (Paulinas, São Paulo 1992) 723-736. F. Chenderlin, "Do This as My Memorial". The Semantic and Conceptual Background and Value of Avó $\mu v \eta \sigma \mathrm{s}$ in 1 Corinthians 11:24-25», Analecta biblica, 99 (Biblical Institute Press, Rome 1982). C. Giraudo, La struttura letteraria della preghiera eucaristica, 124-125. 
de alianza, con sus dos partes (la sección anamnético-celebrativa y la sección epiclética) sin repetir la narrativa de la institución que solo posteriormente habrá sido introducida como lugar teológico escriturístico de la eucaristía. Lo importante, por tanto, es hacer el memorial de la Pascua de Cristo y ofrecerlo al Padre. Y eso es declarado claramente en la anáfora de Addai y Mari. En la eucaristía de la Didaché y en la Tefillá dominical de las Constituciones Apostólicas VII, 33-38, tal vez tengamos dos vestigios de esas paleoanáforas ${ }^{53}$.

El relato institucional -y más exactamente las llamadas palabras de la consagración reducidas al mínimo denominador común de Esto es mi cuerpo y Esto es mi sangre- al que la teología escolástica ha dado tanta importancia, atribuyéndole eficacia exclusiva para realizar la eucaristía, deben ser, desde ahí, relativizadas y puestas en su contexto: la plegaria eucarística, donde ellas tienen la tarea de convencer a Dios Padre de que cumpla la promesa de Jesús, enviando el Espíritu Santo sobre los dones y, por ellos, sobre la asamblea. Dicho de otra forma: la función de la narración de la institución no es realizar la magia de la transubstanciación, sino, dirigiéndose al Padre, recordarle la alianza, por cuya fuerza tenemos el derecho (¡derecho de alianza!) a que venga el Espíritu Santo sobre las ofrendas y las transubstancie en el cuerpo de Cristo para transformarnos en su cuerpo eclesial.

Después del relato y conectando con el orden de reiteración con que él concluye, la anamnesis explicita la intención de la asamblea reunida: hacer el memorial. Ese elemento de la anáfora se compone, en todas las familias litúrgicas, de dos elementos constitutivos: la declaración anamnética y la oferta del memorial ${ }^{54}$, como se encuentra claramente, por

53 Cf. C. Giraudo, La struttura letteraria della preghiera eucaristica, 249-260.277295. ID.: Eucaristia per la chiesa, 346-348.

54 La PE III para misa con niños, en el original latino, es, en ese sentido, anómala: en vez de ofrecer al Padre el memorial de la Pascua del Señor, nos ofrecemos a nosotros mismos. Semejante a la anáfora metodista The Great Thanksgivings. United Methodist Word and Table 1 [en línea] (Nashville, Tenn. 1992) [Fecha de consulta 20 octubre 2005]. Disponible en:<http://www.revneal.org/communionlit1.html >. Fuente: The United Methodist Book of Worship (The United Methodist Publishing House) referido por R. DALY, «Sacrificial Language and Rhetoric in the Church's Eucharistic Prayers: Ecumenical Considerations», en Ecumenism East and West. The 19th International Congress of Jesuit Ecumenists. Lviv, Ukraine, 15-20 July 2007 (Secretariat for Interreligious Dialogue [Curia S.J.], Roma 2007) 4-54, 21. 
ejemplo, en la PE II: «Al celebrar ahora el memorial de la muerte y resurrección de tu Hijo, te ofrecemos el pan de la vida y el cáliz de salvación».

La anamnesis es, por tanto, el verdadero ofertorio de la misa ${ }^{55}$. Lo que ofrecemos a Dios no es pan y vino. Dios no necesita de esas cosas, como no necesita de ningún otro don de la naturaleza, que ya es de él desde siempre (cf. Sl 50, 9-13). Lo que ofrecemos al Padre, es el memorial de la Pascua de Cristo (es decir: de toda su existencia pascual) en el pan y en el vino eucaristizados.

Entre el relato institucional y la anamnesis, la liturgia romana reformada por el Concilio Vaticano II ha introducido la aclamación anamnética o aclamación memorial atraída por la exclamación: Este es el sacramento de nuestra fe (o, en latín, mysterium fidei [misterio de la fe]). Somos invitados a proclamar el misterio de la fe que es el misterio pascual de Cristo, en el cual participamos por la eucaristía y en el cual el cosmos todo participará cuando llegue la parusía y Dios sea todo en todos (1Cor 15, 28), como ya ahora, en la eucaristía, el pan y el vino se transubstancian en cuerpo y sangre de Cristo, empezando la glorificación del cosmos.

Después del memorial y su ofrecimiento a Dios, se sigue en la anáfora romana la segunda epíclesis, sobre los comulgantes, pidiendo por el Espíritu Santo para que, al comulgar, la asamblea reunida sea transformada en el cuerpo eclesial de Cristo.

\section{c) Intercesiones}

Dentro de la estructura de la plegaria eucarística en general, las intercesiones constituyen la continuación y ampliación de la epíclesis sobre los comulgantes. Esta pedía que la asamblea reunida en la celebración eucarística se transformara por la comunión, gracias a la acción del Espíritu, en el cuerpo eclesial de Cristo; las intercesiones vuelven la mirada a los muchos otros fragmentos del cuerpo de Cristo dispersos por el mundo y tratan de asumirlos en la epíclesis, pidiendo que también ellos estén unidos en el único cuerpo de Cristo. La perspectiva es importante para que se distingan las intercesiones de la PE de las oraciones de los fieles, al final de la liturgia de la Palabra. Las intercesiones de la PE no son una

55 Indebidamente tenemos la costumbre de llamar de ofertorio la preparación de las ofrendas. 
serie de intenciones que repiten, de alguna manera, lo que ya ha sido pedido en las oraciones de los fieles.

En general las PEs presentan intercesiones por la jerarquía, por los difuntos, por los santos. A cada una de esas intercesiones se debería poder añadir, en forma de aclamación: "Que sean un solo cuerpo", como lo hace el original latino de la PE II para misa con niños. En ella, según el original latino, después de cada intercesión, la asamblea aclama: «Que sean un solo cuerpo, un solo espíritu para tu gloria, Señor» (Unum corpus, unus spiritus sint ad gloriam tuam, Domine).

Las intercesiones son el lugar de relacionar la eucaristía con la vida concreta del mundo. Así lo hacen muchas anáforas orientales. Como ejemplo, podríamos citar la anáfora de San Basilio en su recensión alejandrina:

"Acuérdate, Señor, también de la salvación de esta nuestra ciudad y de los que en la fe en Dios en ella habitan. Acuérdate, Señor, del clima y de los frutos de la tierra. Acuérdate, Señor, de las lluvias y de las semillas de la tierra. Acuérdate, Señor, del crecimiento medido de las aguas de los ríos. Alegra y renueva la faz de la tierra: riega sus surcos, multiplica sus brotes; hazla como debe ser para la siembra y para la mies, y ahora la bendice de verdad. Gobierna nuestra vida: bendice el ciclo del año con tu benevolencia, por causa de los pobres de tu pueblo, por causa de la viuda y del huérfano, por causa del forastero que está de paso y del forastero residente, por causa de nosotros todos que esperamos en ti e invocamos tu santo Nombre, pues los ojos de todos esperan en ti y tú les das el sustento en el tiempo debido. Compórtate con nosotros según tu bondad, tú que das sustento a toda carne. Llena de júbilo y alegría nuestros corazones, para que, teniendo siempre y en toda parte todo lo necesario, abundemos en buenas obras, para hacer tu santa voluntads ${ }^{56}$.

Se pide por beneficios materiales, pero la razón del pedido está en que la comunidad, "teniendo siempre y en toda parte lo necesario» pueda venir en socorro del pobre, de la viuda, del huérfano, del extranjero. La eucaristía bien celebrada compromete el cristiano. O, dicho densamente: «No hay eucaristía sin lavado de pies» ${ }^{57}$.

\footnotetext{
56 C. Giraudo, Num só corpo [subrayado mío].

57 E. VAn Waelderen, «Diakens: Wakers en voortrekkers in een diaconale Kerk», Collationes, 22 (1992) 344, citado por A. Borras - B. PotTIIER, La grâce du diaconat. Questions actuelles autour du diaconat latin (Lessius, s/1 1998) 27.
} 


\section{d) Doxología epiclética y amén final}

La anáfora empezó con la alabanza a Dios, pero, aun durante la súplica, nunca ha abandonado la perspectiva de la gratitud y admiración que dan espacio a la alabanza. Por eso no es extraño que la plegaria eucarística llegue a su término con una palabra de glorificación a Dios, la doxología que corona el crescendo escatológico que se fue formando con la sucesión de las intercesiones, pues generalmente la última intercesión habla de la patria celestial en la cual entraremos en la perpetua alabanza a Dios anticipada en la eucaristía y resumida en la doxología final. Esa doxología puede ser llamada de doxología epiclética, porque pertenece a la sección epiclética de la anáfora; por otro lado, por su carácter de alabanza, ella vuelve al comienzo de la plegaria eucarística, la sección anamnéticocelebrativa y, con eso, da el cierre final a la totalidad de la anáfora y, por decírselo así, la amarra, subrayando la línea conductora que la traspasa: la alabanza, la confesión agradecida y reconocida.

La última intercesión de la PE romana concluye con Por Cristo nuestro Señor. La doxología está íntimamente relacionada a esta conclusión, por eso no vuelve a nombrar a Cristo, sino sustituye su nombre, en el original latino, por el pronombre ipse: Per ipsum, cum ipso et in ipso (Por él, con él y en él) que prosigue la conclusión de las intercesiones e introduce el final de la plegaria eucarística. El per ipsum no es una pieza autónoma, sino la conclusión de aquella solemne plegaria uno que es la anáfora.

La doxología atrae el amén final de la asamblea. El amén no es un adorno cualquiera. Él es fundamental en la oración y, especialmente, en la plegaria eucarística, como ya lo testimoniaba Justino por el año 165. Ya en el judaísmo, los Maestros de la Sinagoga consideraban más importante decir el amén que pronunciar la oración. Es como en una batalla (de la antigüedad): primero entraban en campo los simples soldados, para que los enemigos se cansaran, después, cuando se acercaba la hora de acabar la batalla (con el declino de la luz del día), entraban en acción los guerreros más notables, los héroes. También en la oración: quien dice la última palabra, el amén, es el más importante ${ }^{58}$.

58 Cf. C. Giraudo, Num só corpo, 387-388. 
Agustín tiene una comparación muy elocuente. El amén es nuestra firma ${ }^{59}$. Cuando se escribe un documento (por ejemplo, un testamento), el texto no tiene ningún valor, mientras no tenga la firma del testador. El amén es la firma de la asamblea a la oración dicha por aquel que la preside. Es ella quien valida la oración. Quien firma es el pueblo de Dios, el pueblo sacerdotal. La plegaria eucarística no es la oración del obispo o del cura que preside, sino la oración que él hace en nombre de la asamblea. La comunidad, al final, la confirma con el amén: «Estamos de acuerdo. Así es. Así sea». 
Resumen: El artículo empieza con la explicitación del principio lex orandi - lex credendi que será la base de la reflexión. Si aceptamos este axioma como válido, el camino más propio para discurrir sobre la teología de la eucaristía será el análisis de las plegarias eucarísticas de Oriente y Occidente. Al seguir esbozaremos la estructura literaria de ese tipo de oración de la Iglesia, identificándola como oración de alianza (todá), tal como se encuentra en la tradición veterotestamentaria continuada en el judaísmo. Finalmente llegaremos al cierre del artículo, que es constituido por un análisis de las plegarias eucarísticas romanas, desde las cuales descubriremos la teología de la eucaristía revelada por el mismo texto central de una celebración eucarística que es esa plegaria -según la terminología de las Iglesias Orientales- la anáfora.

Palabras clave: Lex orandi - lex credendi; oración de alianza (todá); plegaria eucarística; anáfora.

Abstract: The article begins with the explanation of the lex orandi - lex credendi principle, which is the basis of reflection. If we accept this axiom as valid, the most proper way to discourse on Eucharist theology is the analysis of Eucharistic prayers of the East and West. We then outline the literary structure of this type of church prayer, identifying it as a prayer of alliance (todá) as found in the continuing Old Testament tradition in Judaism. Finally, we reach the core of the article, which is an analysis of Roman Eucharistic prayers, from which we discover the theology of the Eucharist revealed by the central text of this prayer expressing a Eucharistic celebration, according to the terminology of the Eastern Churches, the anaphora.

Keywords: Lex orandi - lex credendi; prayer of alliance (todá); Eucharistic prayer; anaphora. 